\title{
モルモットに㧍ける内リンパ水腫生成と，外側半規管切断による 水腫減退に関する実験
}

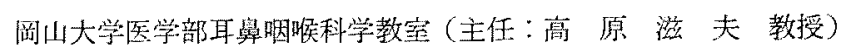

$$
\text { 小四静雄 }
$$

\section{要 㬅}

I. 目的:

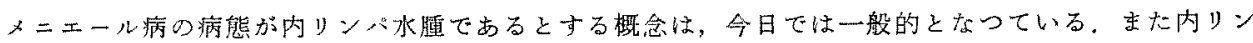

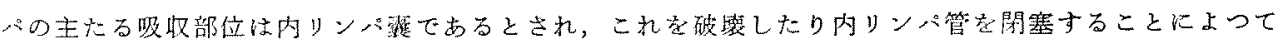
実䮖的に内リンパ水腫を生成し得ることが報告されている。

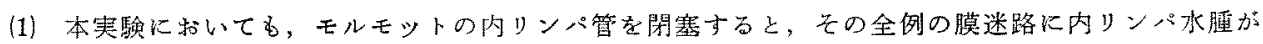
生成されることを磪認したので，

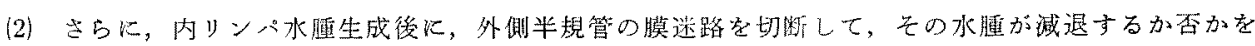

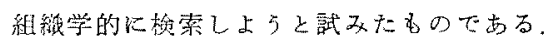

II. 害娩 1 :

(1) 実䮖力法;

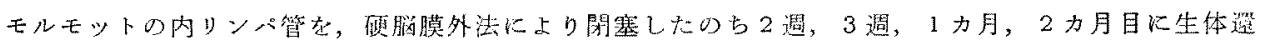

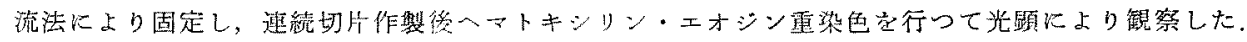

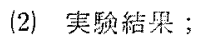

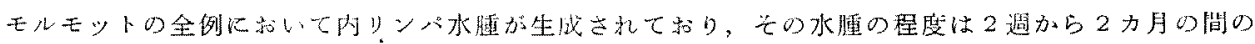

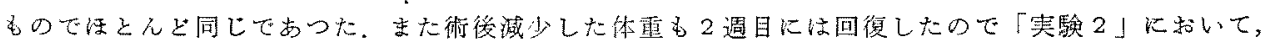
内リンハ管閉塞㣭15日日に外側半烧管な切断することにした。

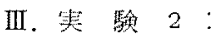

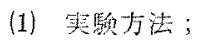

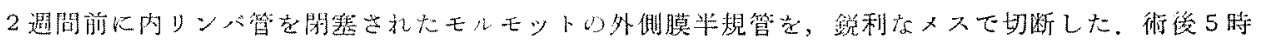

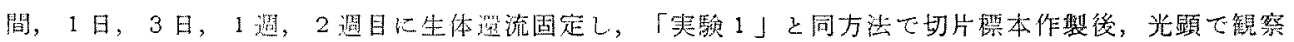
した。

(2) 勧雅船果;

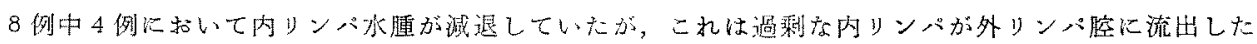

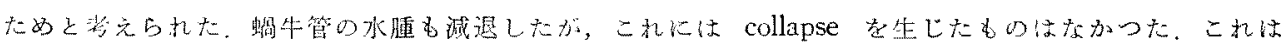

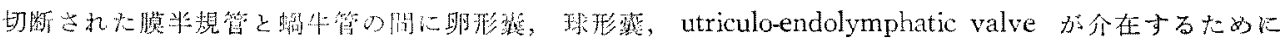

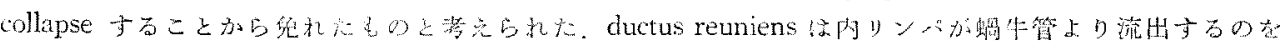

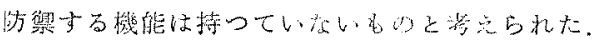

内リンハ水琏の持続しれ4侧は，外俳膜半規管が再閉鎖したため，あるいは内耳炎を合併したために 生したものでるつた。

IV. 結 语:

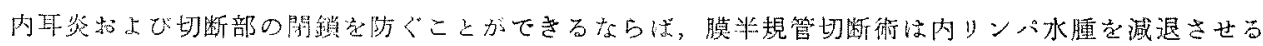

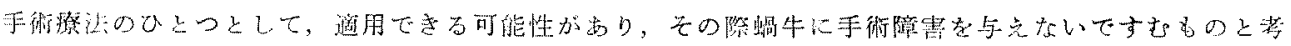
它礼た。

\section{1 緒}

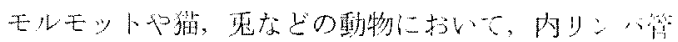

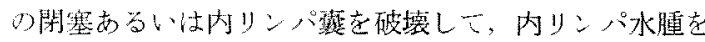

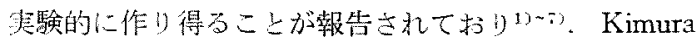


and Schuknecht ${ }^{1)}$, Kimura ${ }^{2)}$ はこの事実を次の上5に説 明している。つまり，物動の内リンパ管を閉塞したり， 内リンパ筑を破壤する上，内リンパの吸収される部位を 失なつて，その結果内リンパが蓄穦し内リンパ水腫の状 態を呈してくるものであるらと述心，その他の研究者 も，内リン゙パ霆は内リンパを吸収する機能があるとする 概念を支持している3) i

一方, Hallpike and Cairns ${ }^{8)}$, 山川 ${ }^{9>}$ らの暎告以来, メニエール病は内リンパ水嗹に基づくものであるとする 考えが一般化してきた，その内リンパ承腫を消失させる ために，多くの手術方法，すなわち，内リンパ䔶手術10〉 ${ }^{153}$, sacculotomy ${ }^{16) \sim 183}$ ，などが考案され，実際に治療上 して施行さ机ている。

さらにShea ${ }^{19}$ ), Femenic ${ }^{20)}$ は外側半規管の膜迷路 (以 下，膜半規管と記す）を切断する手術療法を行い，その 臨床結果は㯖覚機能を保存した状態で耳鳴・矓鼠を消失 し得て，きわ的て满足す心゙きものであったと述心てい る.つまりこの方法は膜半規管を切断することにより， 内リンパを外リンパ腔に流出させて内リンパ水盾を消失 させ，一方その手術部位と螖牛とが遠距離にあるので， 蝸牛の受ける手術影響が少ないであるらことが期待され たものである。

本実験の目的は，第一に，モルモットの内リンハ管老 閉塞して内リンパ水腫が全例飞生成さ机ることを確認 し，第二に，その水挝が膜半規管切断することによつ て減退するか否かを組織学的に検索することにある。 こ とに, 内リンパ水腫減退の目的で膜半規管切断衙が行わ れた場合，螖牛にどのような影響がおよぶかが注目され た.

\section{II 内リンパ水腫生成の実験}

1. 䨋験材料㧍よび方法

体重 410 660g でプライエル反射正常で身体平衡障害 のない健康なモルモット老使用し，乎術操作をとの右耳 に施し，左耳には操作孛加えないで比猶対照に供した。

ネムブタール $30 \mathrm{mg} / \mathrm{kg}$ 体重の腹腔内注射により麻醉 を行い，手術用顕微鏡下で無菌的に手術を行つた。㣪頭

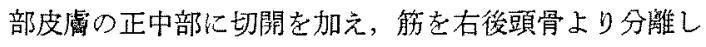
たのち, Shea の手術用ハンドドリルにより右後頙骨に 小さな穿孔を作り開頭した，頭蓋腔内に扣いてS 状静脈

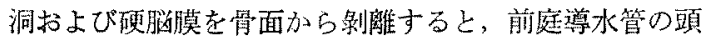
盖口が静脈洞の直前に現孔る。 その前庭導水管の入口部 で内リンパ簖に切開を加えたのち，導水管内の内リンパ 徒を，ハンドドリル老用いて内リンパ管の近くまで破壤
した（図 1)，破壊された内リンパ管より内リンパが流 出するのを防ぐために，直ちにその部に骨蠟をつめた。 後頭骨の穿孔部には Geltoam 片を充堚し，箭肉および 皮鬳をそれぞれ縫合した。

術後は4日䦥, 1日20mgのテラマイシンを筋注した。 一定日数経過後モルモットをネムブタールで樑麻酔を行 った後に，生食水で生体還流を行い，さらに Heiden一 hain-Susa 液を邉流して固定した。用いられた動物の数 は，術後 2 週目が 6 匹，3 週目が 1 匹，1 1 月月目が 1 匹，2力月目が 2 匹である。

両側頭骨は，譄をそのままの位置に残置して en bloc の状態で摘出し，型のごとく固定を十分に行い，5\%三 塩化酩酸で脱灰し，アルコールで脱水，七ロイジンで包 埋した。両耳は水平断面で $20 \mu \sim 30 \mu$ の連続切片とし 5 枚目毎をへマトキシリン・エオジンで重染色した。切片 標本は光学顕微鏡の下で観察し, 左右耳の同領域を組織 学的に比較検索した. 更に詳しい椧萦の必要な場合, こ とに ductus reuniens, utriculo-endolymphatic valve $\Phi$ 観察には切片を追加染色した。

\section{2. 実駼結果上考按}

内リンパ管の閉塞後, モルモット注自発眼振もふらつ きも示さなかつた. 動物の体重は手術後 $7 \sim 11$ 日の閣に 約25\%の減少が見られたが，ほとんどの動物は術㣪 2 週 目には街前の体重に回復した。

組織学的推察の結果は, 全例に执いて, 破壊された内 リンパ整の部位に線維性の結合組織をたは骨組織(図9) が形成されていること，そして膜迷路に内リンパ水腫の 生じていることが明らかとなった。ドリルした前庭尊水

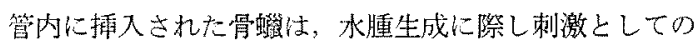
影響がないことが Kimura ${ }^{2}$ に上り示されている。

水腄の程度は 2 週間加ら2力月の間のものに㧍いてほ 上んど同じ状態のように見られる。すなわち，螖牛管の 搪張は全回枟に㧍よび (图 2), ductus reuniens, saccule, utricle, saccular duct, utricular duct, sinus of endolymphatic duct 按張し，ことに saccular membrane は 鐙骨板に達して接着している(図3). Kimura and Schuknecht $t^{1)}$, Kimura $^{22}$ \&術後 2 週目の時期に saccular membrane が鐙筒板に達していることや, saccular duct や ductus reuniens が拉張していることなどを報告して いる. 柳》电術後 $2 \sim 3$ 週目には螖牛管, 球形藻上も に, その水腫の程度は “高度” 儿澾し, それ以後時間が 経過しても，必ずしも強い水腄が起こつているとは限ら ないと述べてる。 
半規管とその膨大部に核変化は見られないが, common crus はわずかながら应張していた, utriculo-endolymphatic valves 10 例中 3 例が開いていた。感覚細

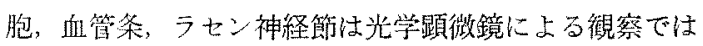

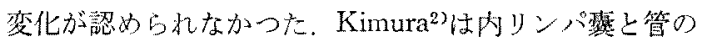
破㠃閉鎖後 $1 \sim 2$ 力月で10例中数例に扣いて，蜩牛の頂 部上第 3 回転に限つてではあるが感賞細胞， ラセン神経 節，血管条に変性の生じたことを記述している。

比較対照に低した左耳では水腫はなく，utriculo-endolymphatic valves 法全例において開鎖またはほとんど閉 した状態であつた。

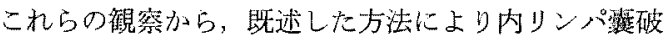
壞および内りン八管閉塞老行らことによつて，全例に内 リンパ水腫が作られることを確認した。(詳細恃别䇉にて 報告の予定である.)

以上のごとく，実験動物は概して術後 2 週間の5ちに 術前の体重に回復すること，そして水腫は術後 2 週間加

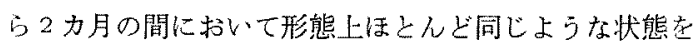
示すことが判明したので, 内リンパ管閉塞後 2 週間たつ て，次に述心゙るよな膜半規管の切断形を施行すること にした.

\section{III 内リンパ水腫が生成されたモルモットの膜 半規管を切断した実験}

\section{1. 奏雅材料打上び方法}

内リンパ水腫を持つモルモットの膜半規管を切断した 時,どのような形態的变化が生じるがを観察するのが目 的である.

モルモットは既述した方法で，すでに2週間前に内り ンパ管が開塞されている10匹が使用された。 ネムブター レの腹腔内注射によつて麻酔を行い，手術用顛微鏡下に 施術した. 右後頭部皮膚切開を加え, 筋定分雕して右側 の bulla tympanica の後面起露出し，手術用ハシドド

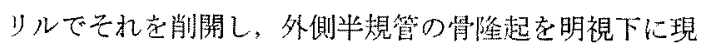
した，外側半規管の骨壁を注意樑くドリルで削除し，長

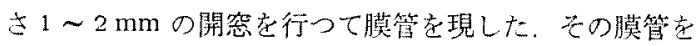
鋭利なメス安用いて外リンパの中で切断したのち, 外側 半規管の開空部索筋膜で被い（図 1)，表在の筋战よび皮

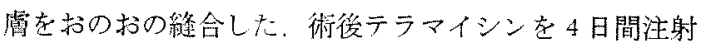
し感染了防に努力た。

モルモットは術後 5 時閒か63 週の間の各々異なつた 時期において，甈述の生体還流固定法を行つた，また寸 でに述バたと同し力法で側頭骨を摘出し，さらに切片標 本を作製して光学影微鏡で観察した。

\section{2. 実験成績}

すぶてのモルモットに招いて，膜半規管切断後の2 3 日閒は水平の自発眼振があり，4〜6日間は運動時に ふらつきが生じた。なお手術礼たモルモットのうち, 1 匹は飼育中に術後4 日目で死亡し，他の1匹（3週 目）は標本作製中に技術的 artifact が加わつたので，残 りの8匹について形態学的観察を行つた.

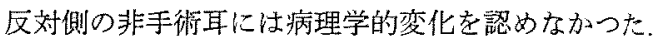

手術した 8 耳の観察結果, 内耳膜迷路の形態学的状態 は拉扩よ之2群に分けられ，それを表1に示した。

つ里り第1群は内リンハ水㯖が軽減もしくは消失して いるもので 4 匹が属する。 それら忟表に示したように， 蛹牛管では 3 耳に䄧いて水腫加減少または消失を示して

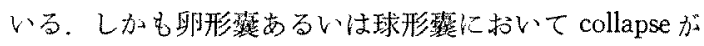
見られる場合でも，蝸牛管には collapse が生じていな 以な挍，蛸牛管に扣ける水腫の減少の程度は術後 5 時 間のものより3〜7日のものの方が大きい(图 8).

寸心゙ての卵形整の下部に执いてその水腫は消失してい て，2 例では collapseしているが，卵形露の上部では㹡 大したままのものが 2 例ある(図10).4耳の球形整の5 ち2耳は collapse に陌り（図9），1耳は正常な籁囲内に あり，他の1聑なお桩大したままである(图6).

4 耳とも内リンパ腔内には異状は見られないが，2耳 において外リンパ腔に浆液性浸出物と赤血球が見られ た。すなわち，術後５時閒目の No. 61 では，外側半規 管と前庭の外りンパ腔に赤血球と漿液性浸出物が少しあ り，前庭に近、䖮牛前庭階にもわずか子獎液性浸出物が 見られる。術後 1 週目の No. 38 においては, 古い赤血

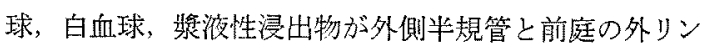
パ腔に，そして基底回車の前庭階にも見られた（図 8 ， 9).

3耳の中耳腔に血液の貯留が見られたが，他の1耳 (No. 38)の中耳腔沈きれいだあった。

球形稢が㹡張していた例においては (No.61) utriculo. endolymphatic valve が閉じていたが，これは著しく拉 張した球形露によつて卵形踧膜が圧迫されたため，その

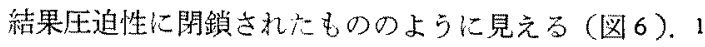
週目の例 (No. 38) における valve の開錤は卵形霍の下 部の collapse のためである(図9).

第 2 群は水腫の消失しなかつたもので 4 匹が属する.

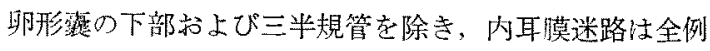

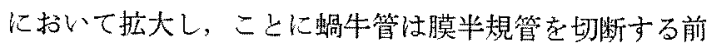
に比較して抾大が著しい 
日耳鼻 小西ニモルモットに扔ける内リンパ水腫生成と,外側半規管切断による水腫减退に関する実駼 $77-123$

表 1 内リンパ水腫生成後に外側半規管の膜迷路を切断した場合の内耳の所見

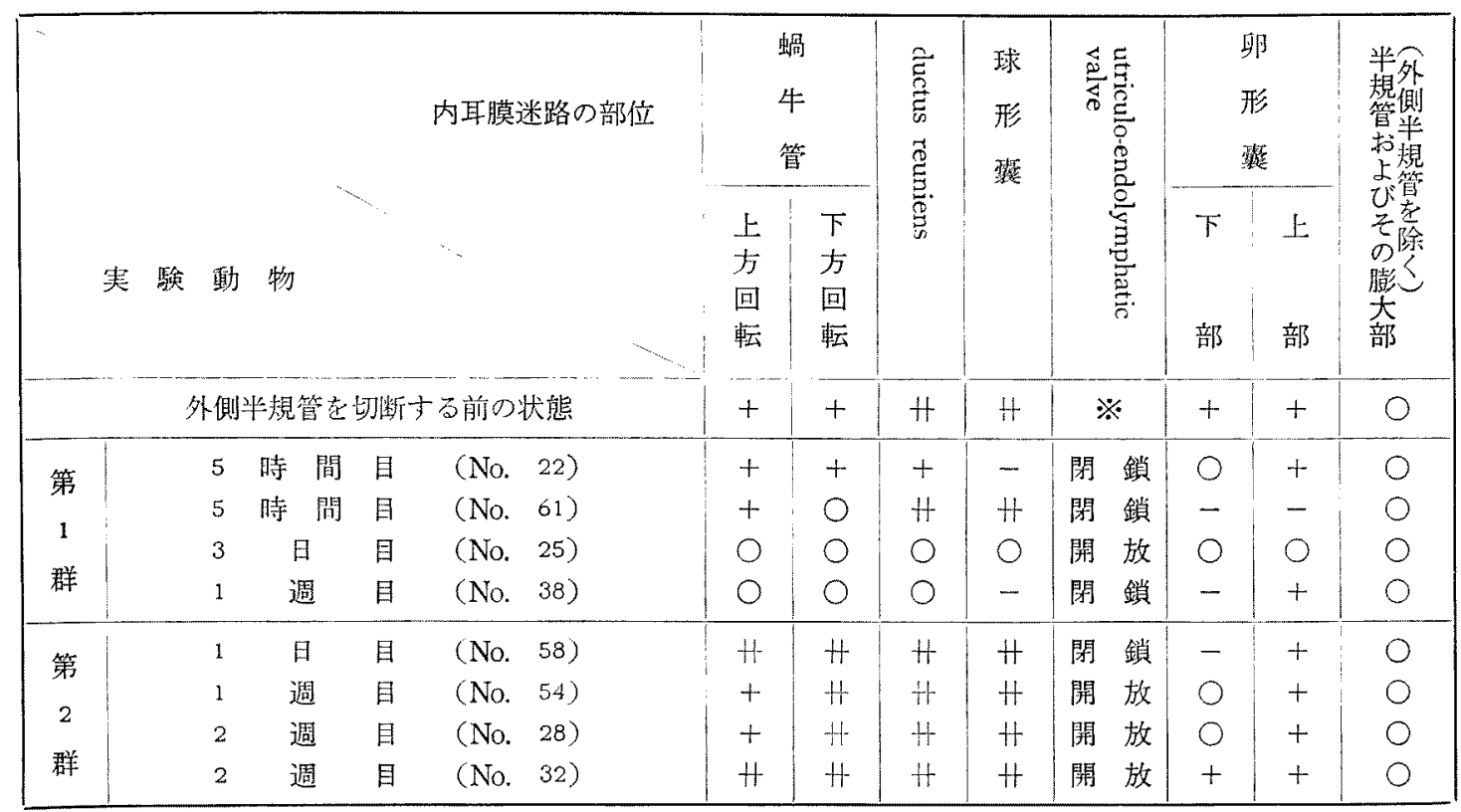

＃ 拡大顕著, 十 挔大中等度, ○正常範囲, 一 低圧あるいは collapse

※10匹のらち3匹に捛いて開放していた

術後1日目の場合 (No. 58) には, 内リンパ系の pars superior（卵形整と三半規管）において赤血球が見ら れ，外リンパ腔では赤血球と多核白血球が三半規管，前 庭, 螖牛の低回転の前庭階に存在していた（図 11)。 そ の valve は, 球形露が抬張し卵形露の下部が collapse しているにも拘らず閉鎖していたが，これは桩大した球 形雚によって圧迫性に閉鎖した No. 61 と同様所見であ つた．基底回転に㧍ける血管条には退行変性が見られ た．また中耳腔や肥厚した正丹空膜，およびそれに近い 鼓室階の中にも多核球が存在していた。

1 週目の例（No. 54）では内リンパ系の污染忙見られ ないが，多数の多核球が中耳腔にあり(図12), 同時に 少数の白血球が肥厚した正円空膜とか，それに近接した 鼓室階や，前庭内の一部にも見られた。

2 週目の場合の 1 例（No. 28）に招いては, 少数の古

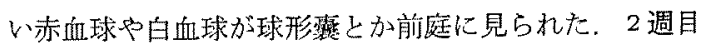
の他の1例（No. 32）に押いて活半規管膨大部や卵形 雚, 球形整などの内リンパ腔に古い赤血球や多核球が存 在し，同時に球形琵斑や，蝸牛の低回転における感喾細 胞，血管条に退行変性が見られた。な秥古い赤血球は前 庭腔や頂部に到るまでの蝸牛前庭階の中にも存在した。
術後 1 週目以後にわける例においては，切断術が行わ れた外側半規管が線維性の結合組織で充満され完全に閜 鎖されていた（図13)。

膜半規管切断術に供された 8 耳全例において，操作さ れた外側半規管を除く他の半規管には変化が認められな かつた。 また明らかに collapse したと思われる ductus reuniens はなく, 球形霆が collapse した例 (No. 22) に 捻いてすら ductus reuniensは拉張していた。

3. 考按

内リンパ水腫を持つ 8 耳の膜半規管を切断したとこ 万，その水腫は 4 耳に沶いて消失もしくは減退している のが認められた，これは，膜半規管の断端部から過剩の 内リンパが外リンパ腟に流出したために水腫が消失した ものと思われる。，その際，卵形焣または球形露が collapse している例に执いてさえも，蝸牛管は collapse 寸 ることがなかつたが，これは蝸牛管が手術された膜半規

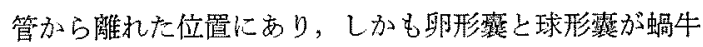
管に先んじて低圧となり更には collapse に陷つてしま うために，螖牛管が collapse 支ことから免れたもの と考えら机る。 さらに utriculo-endolymphatic valve は 卵形嚄の下部が collapse すると No.61，No. 38 に見ら 
れたように，扔のずから閉鎖するので，これも内耳膜迷

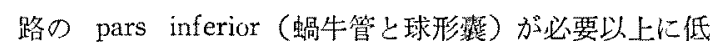
圧となることを防ぐのに役立つていると思われる。

内リンパ水腫の減退したグループに扔いても，No. 22,

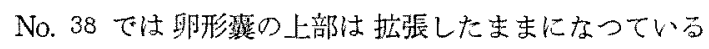
が，これは卵形整の上部が骨胞に包ま机ているために， ひとたび拡张すると容易に縮小しにくくなつているもの であるら。

No. 61 で見られたよらに，蝸牛管や卵形得の圧が隇 退しているにも方かからず球形裂のみが著明に拉張した ままになっているのは，その機構を説明することが困難 である。

Kristensen ${ }^{211}$ は, 聴力検查法として Preyer reflex 用いて検查した結果, モルモットの膜半規管の切断䚘を 行つても䏇力に障害を生じることはなかつたという箺験 的研究を報告しているが，このことは本実験で膜半規管 を切断しても，螖牛管に collapse を生じなかつたとい う形態学的観察汃らも首肯される。鳬故メニエール病 の上5に内リンパ水腫を持つ患者に対し, 水腫を減退さ せる手術的療法のひとつとして償半規管切断術を適用で きる可能性があり，そ心際蝸牛に障害を与えないですむ ものと推測される。

内リンパ水腫を持つ患者に対しても，緒言で記したよ $5 に$ Shea $^{19}$, Femenic ${ }^{20)}$ は膜半規管を切断し, 内り之 八゚采から外りンパ腔に永続的な流机を作ることにより， 满足すべき結果を得たと述べている。

しかしながら本実験の第 2 群で示されているように, 術後に内耳炎が生じたり，または切断された膜半規管が 䦥鎖したりすると，水腫が再び発生する可能性があるこ とに注目しなければならない，すなわち，顕著な水腫を 起こしたままになっていた 例について見ると，その原 因は, No. 58 では術後性迷路炎, No. 54 では切断され た膜半規管の闒鎖と化膿性中耳炎によってひき抗こされ た内耳炎の合併，そして No. 28 N. 32 では術直㣪 の術後性迷路炎之膜半規管切断部の閔鎖の合併により生 じたものと考えられた。

Shambaugh and Takahara ${ }^{29}$ 注術後性内耳炎に起因し た内リンパ水腫を報告し, 内耳内一の出血は術後性漿液 性内耳炎の1つの重要な原因となることを强調してい る、したがつて細菌感染を防ぐこ上はもらろんである が，内耳一の出血を餢けることもきわめて重要なことで ある。

切断された膜半規管が再び開鎖するならば，一县減退
していた水腫が再度生じることは当然考えられる，Femenic ${ }^{20)}$ によって示された方法法，この閉鎖を防くのに 有効である上思われる。すなわち彼は，切断した膜半規 管の膨大部側の端を開空部から折り曲げて外に出し，そ のまま開空部を軟骨あるいは適当な材料によつて作られ た stopple (栓)によつて閉鎖し，更にそれを結合組織 によつて被㠅寸る方法を用いている、この方法によれ ば, 移植された結合組織からの新生組織が, 外側骨半規 管内に侵入することを防ぐことができるものと思われ 万.

utriculo-endolymphatic valve は, 反対側の非手術耳 ではほとんど閉じているかなたは閉鎖した状態である が，このことは過去の文献にも報告されている 23) -26) これに対して，内リンパ管の閉塞後に战いては valves の約 $1 / 3$ が開放していたが，この事実は pars inferiorの 圧が pars superior よりも高いかるるいはをれらの圧が 互いに等しいといらことを示すむのであろう． Bast ${ }^{27228)}$ は valve の機能について, 球形囊之螖牛管内の圧が急 激に減退した時に, 卵形蓝抢上び膜半規管内の圧を正常 に維持するために作用するものであると記述している. Igarashi2 ${ }^{29}$ は実験的に球形埕膜を破損した後に valve が 閉鎖するといら事実を示し, pars superior が collapse するのを保護するものであるらと述べている。

彼の㬰験しは反対に, 内リンパ管を閉塞した本赛験で は, valve のいくつかが開放になつていたが，このこと はおそらく著明なる水腫を有するところの pars inferior から pars superior に内リンパが流通しうる状態を示す ものであるら。

膜半規管を切断した後では, valve は No. 25, No. 54, No. 28 , No. 32 で開放していたが，No. 25 ではとくに pars inferior から pars superior に内リンパが流通す るのに合理的であつたといえる. No. 22, No.38（図 9） の2 例では球形薄が collapse して valves が閉鎖してい た.これらの所見は pars superior へ内リンパが必要以上 に流出与るのを防いでいることを暗示しているようであ る.その他の valve の閉鎖していた例 (No.61 (図6),

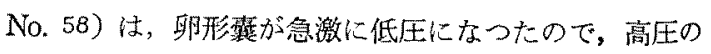
球形築によつて圧迫されたもののよらにみえる。これら の所見からすると, utriculo-endolymphatic valve は, Bast ${ }^{27) 283}$, Igarashi'29) 減退した時に pars superior 䘮保偝するという作用にと どまらず, 内リンパ水腫が存在する場合には, pars superior で内リンパの消失が急激に生じた時にもpars 


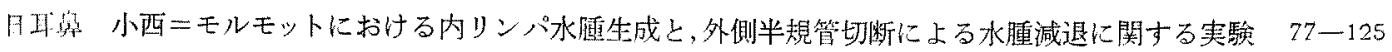

inferior を防䓚寸るのに有効であると桨えられる。しわ し No. 61, No. 58 のよ5な場合には，その後の時間の 経過としもに，扟らく valve は次第に開放してきて 内リンパが pars superior に再び流れ始めるであるらと 推量される。

ductus reuniens は内リンパ管索閉塞した状態では著 しく搪張して々た，膜半規管を切断してその内リンパ水 腄索隇退させた場合には，乙の ductus reuniens も縮小 する㖽向はあつたが，予期に反して球形票が collapse した例においてすら ductus reuniens 加払張したままに なつているものがあつた (No. 22). ductus reuniens どちらかといらと，内リンパが蛆牛管より流出するの索 防禦する機能は持つていないもののように考えられる。

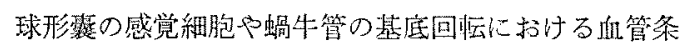
などの変性が No. 58，No. 32 に兒られたが，これらの 例では膜半規管切断後にも水腫が持続し，多核白血球の 浸閏が内耳にあつたものであり，それらの翌性は怙てら く内耳炎によるものと考えられる。

\section{IV 結語}

内リンパ管を閏塞したモルモットの全例に扔いて，内 リンパ水腫ができること意まず確認した，その水腫は球 形整，螖牛管において影著であつた。

内リンパ水腫を生成した後そのモルモットの膜半規管 老切断すると，8例中４例に招いて水腫が減退してい た，水瘇は，括そらく過剩の内リンパが外リンパ䐋に流 出することにより，減退したものと考光られた，水蕾の 隇退した4例の内耳に扔て，螖牛管が collapse した ものは1例もなかつたが，これは蛸牛が手街された膜半

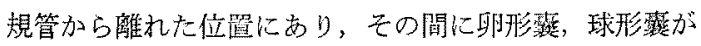
介在していることと, utriculo-endolymphatic valve があ るために collapse から免れたものと考えられた。

内リンパ水腫の持続した他の 4 例に扔いて, その原因 は切断された膜半規管が冓び閉鎖してしまつたこと，中 たは内耳炎によるものであつたと考えられた。

以上の結果より，膜半規管の再閉鎖㧍よび内耳次を防 ぐことができるならば，内リンパ水腫を消失させる手術 療法のひとつとして，膜半規管切断術を適用できる可能

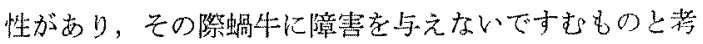
えられた。

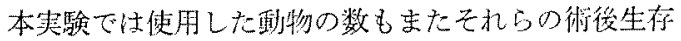

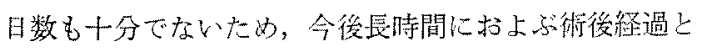
多数の動物による类駼観察が望票れる。
本研究は Memphis Foundation of Otology (Director: Dr. John J. Shea, Jr., Tennessee, U.S.A.) の fund より行われたものである。

擱筆火当り，ご校閲を睗つた恩哪高原滋夫教授，小何 䣡郎助教授に感䚴申し上げます。

な特，本研究の要旨は，策94回日耳鬼中国地方会( 48. $7 \cdot 8)$ ，第14回日耳與中国四国合同地方会 $(48 \cdot 11 \cdot 11)$ ，第 1 回日本耳科学会総会 $(48 \cdot 11 \cdot 23)$ に拈いて登表した。

\section{文献}

1) Kimura, R.S., and Schuknecht, H.F.: Membranous Hydrops in the Inner Ear of the Guinea Pig after Obliteration of the Endolymphatic Sac. Pract. Otorhino-laryng., $27 ; 343-354,1965$.

2) Kimura, R.S.: Experimental Blockage of the Endolymphatic Duct and Sac and Its Effect on the Inner Ear of the Guinea Pig. A Study on Endolymphatic Hydrops. Ann. Otol., 76 ; 664-687, 1967.

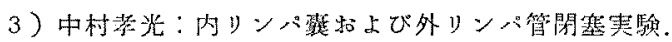
日耳发。 $70: 932 \sim 941,1967$ (昭42).

4) Schuknecht, H.F., Northrop, C., and Igarashi, $M$.: Cochlear Pathology after Destruction of the Endolymphatic Sac in the Cat. Acta Otolaryng., 65; $479-487,1968$.

5) Beal, D.D.: Effect of Endolymphatic Sac Ablation in the Rabbit and Cat. Acta Otolaryng., 66;333$346,1968$.

6) 宇野雅明：内リン八水腫の際の蝸牛機能に閔する䒠 歌的研觉。日耳鼠，72：1115-1128，1969（昭44).

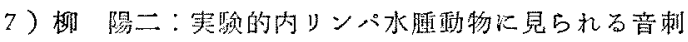
湤による螖牛ラセン器 (organ of Corti) の形態学的

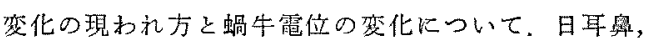
$76: 61-75,1973$ (昭48).

8) Hallpike, C.S., and Cairns, H.: Observations on the Pathology of Ménière Syndrome. J. Laryng., 53; $629-655,1938$.

9）山川強四郎：ハニェール氏症候を呈せし患者の聴 器. 大日耳鼠，44：2310 2312，1938 (嚾13).

10) Portmann, G.: Surgical Treatment by Opening the Saccus Endolymphaticus. Arch. Otolaryng., 6; $309-319,1927$.

11) House, W.F.: Subarachnoid Shunt for Drainage of Endolymplatic Hydrops. Laryngoscope, 72 ; $713-$ 
$729,1962$.

12) Austin, D.F., and Hart, G.R.: Short Term Study of Endolymphatic Shunt Operation. Arch. Otolaryng., $81 ; 359-364,1965$.

13) Shambaugh, G.E.: Surgery of the Endolymphatic Sac. Arch. Otolaryng., 83 ; 305-315, 1966.

14) Shea, J.J.: Teflon Film Drainage of the Endolymphatic Sac. Arch. Otolaryng., 83 ; 316-319, 1966.

15) Shea, J.J.: Surgery of the Endolymphatic Sac. In Otolaryngologic Clinic of North America. (ed. J.L. Pulec) pp. 613-621, W.B. Sounders Co., Philadelphia, 1968.

16) Fick, 1.A.N.: Decompression of the Labyrinth. Arch. Otolaryng., $79 ; 447-458,1964$.

17) Fick, 1.A.N.: Sacculotomy for Hydrops. Laryngoscope, $75 ; 1539-1546,1965$.

18) Cody, D.T.R., et al.: Automatic Repetitive Decompression of the Saccule in Endolymphatic Hydrops (Tack Operation). Laryngoscope, 77 ; 1480$1501,1967$.

19) Shea, J.J.: Personal communication Kよる.

20) Femenic, B.: Drainage Operation in Cases of the Hydrops of the Labyrinth and Its Influence on $\mathrm{He}$ aring. J. Laryng,, $75 ; 640-646,1961$.

21) Kristensen, H.K.: Acoustic-Vestibular and Histologic Examinations in Guinea-Pigs after Interruption of Membranous Labyrinth in Semicircular Canals or Cochlea. Acta Otolaryng., $51 ; 382-402,1960$.
22) Shambaugh, E.G., and Takahara, S.: A Clinical and Experimental Study of the Effect of Fenestra. tion on the Labyrinthine Contents. Acta Otolaryng. Suppl., 123, 1955.

23) Anson, B.J., and Wilson, J.G.: The Utricular Fold in the Adult Human Ear. Anat. Rec., 43 ; 251$255,1929$.

24) Hoffman, E.F., and Bast, T.H.: A Comparative Study of the 'Utriculo-Endolymphatic Valve' in Some of the Common Mammals. Anat. Rec., 46 ; 333-347, 1930.

25) Perlman, H.B., and Lindsay, J.R.: The UtriculoEndolymphatic Valve. Arch. Otolaryng., 24 ; 68-75, 1936.

26) Bast, T.H.: The Utriculo-Endolymphatic Valve and Duct and Its Relation to the Endolymphatic and Saccular Ducts in Man and Guinea Pig. Anat. Rec., $68 ; 75-97,1937$.

27) Bast, T.H.: The Utriculo-Endolymphatic Valve Anat. Rec., 40 ; 61-65, 1928.

28) Bast, T.H.: Function of the Utriculo-Endolymphatic Valve. Arch. Otolaryng., 19 ; 537-550, 1934.

29) Igarashi, M.: Histopathological Findings after Experimental Saccular Destruction in the Squirrel Monkey. Laryngoscope, $75 ; 1048-1061,1965$.

（原稿受付 昭和48，10，8日） 
小西論文附図 (1)

DIAGRAMMATIC DRAWING OF MEMBRANOUS LABYRINTH

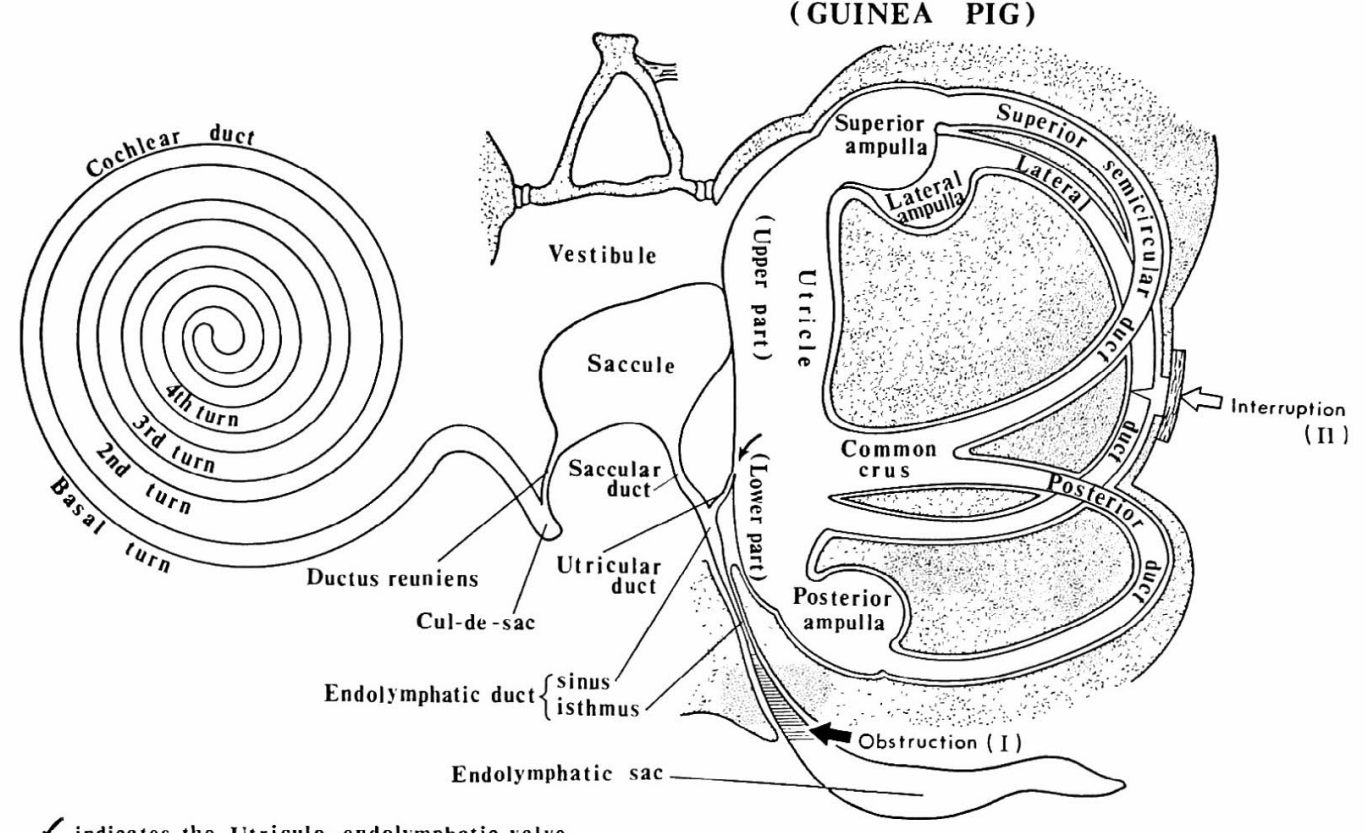

f indicates the Utriculo-endolymphatic valve.

図 1 モルモットの内耳膜迷路（右耳を内耳道側より見たもの）を模式図で現わし，実験操作部位を示す

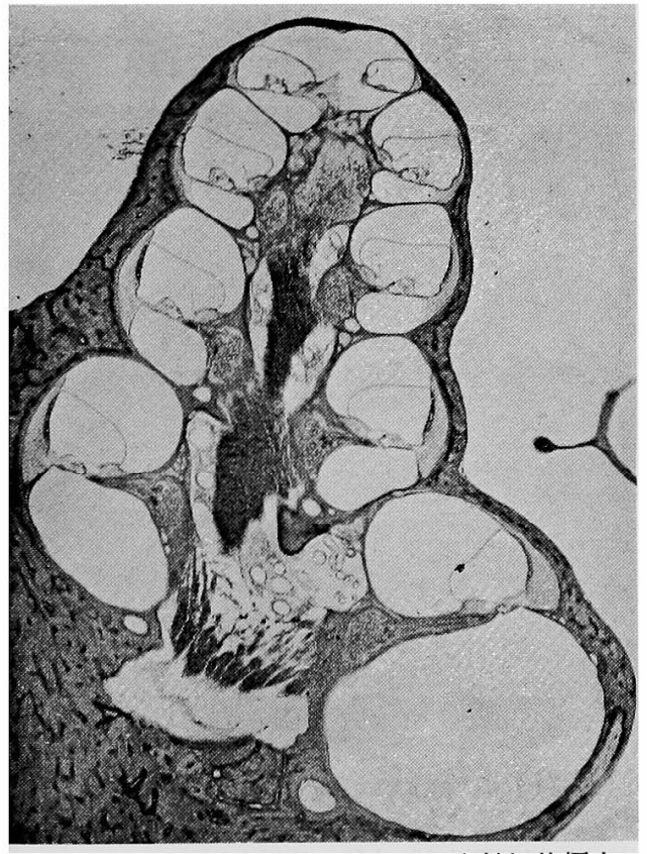

図 2 内リンパ管閉塞後 2 週目の蝸牛軸切片標本の 顕微鏡写真. 蝸牛管の全回転において拡張が 見られる

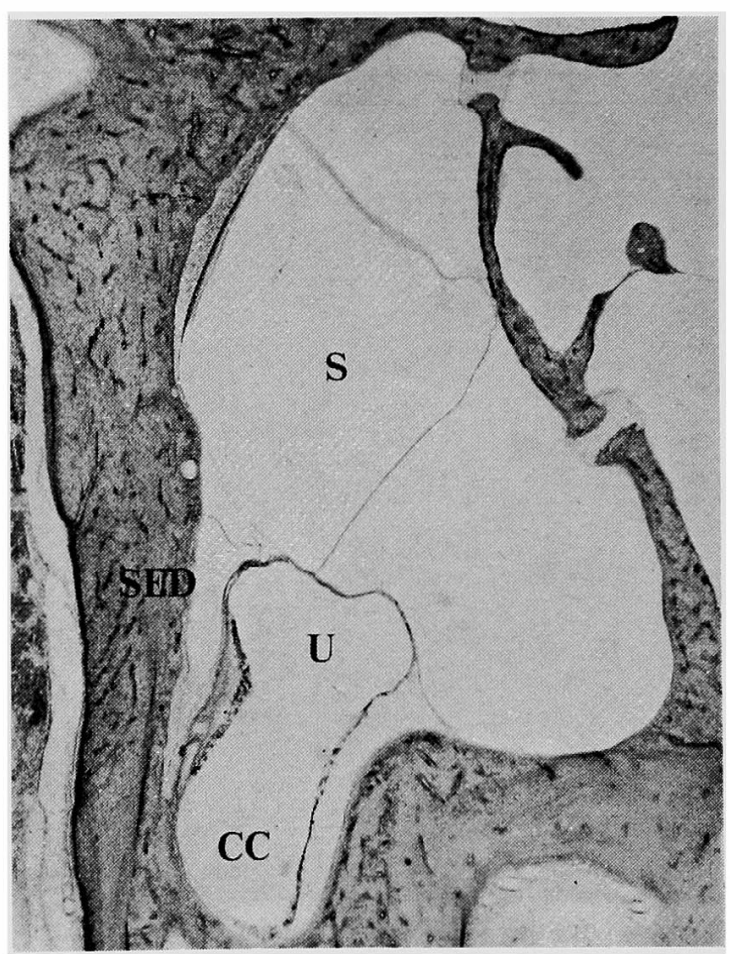

図 3 内リンパ管開塞後 2 週目の前庭の顕微鏡写真. 球形 謽 ( $\mathrm{S}$ ), sinus of endolymphatic duct (SED) の 拡張が見られる。同時に 卵形囊上部および ductus reuniens の昖張も同内耳に見られた。 U : 卵形踺 
小画論

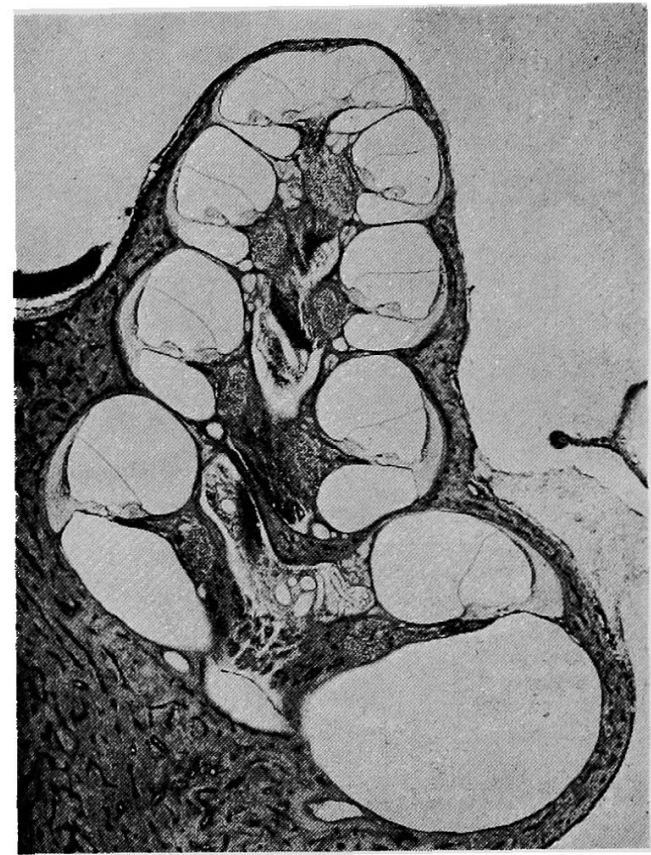

図 4 （No. 61） 内リンパ管閉塞後15日目に，膜半 規管を切断し，その 5 時間後の蝸牛軸切片標 本の顥微鏡写真. 蜩牛管の拡張の程度は下方 回転に扔いて減退している.

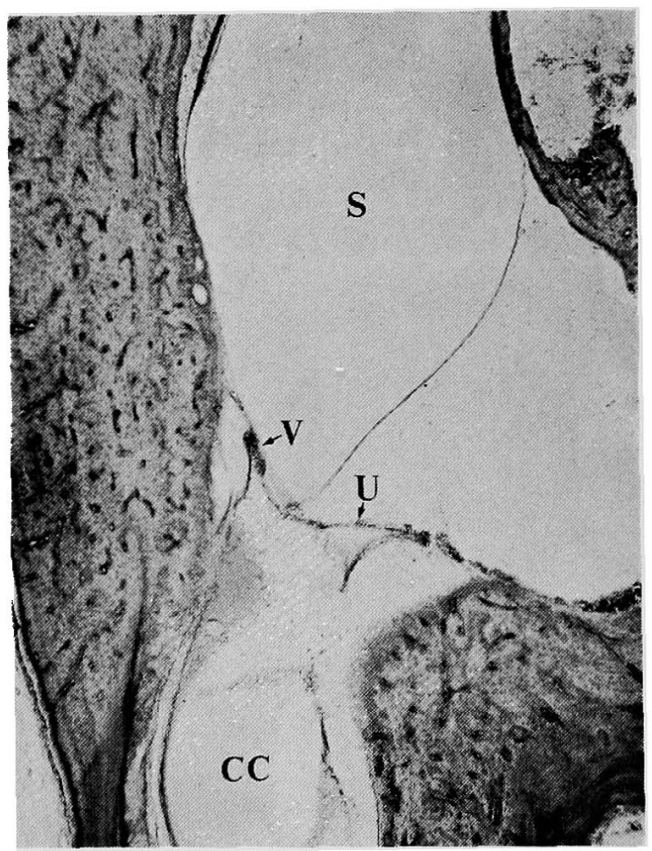

図 6（No，61）図 4.および5. と同耳の前庭顕 微鏡写真. 球形囊 (S) にな打䫓著な拡張が 存在するが, 卵形囊の下部 (U) 仗 ccllapse している。 その結果 valve (V) は球形䝵膜 に压迫されて開鎖している. CC : ccmmcn crus
文附図（2）

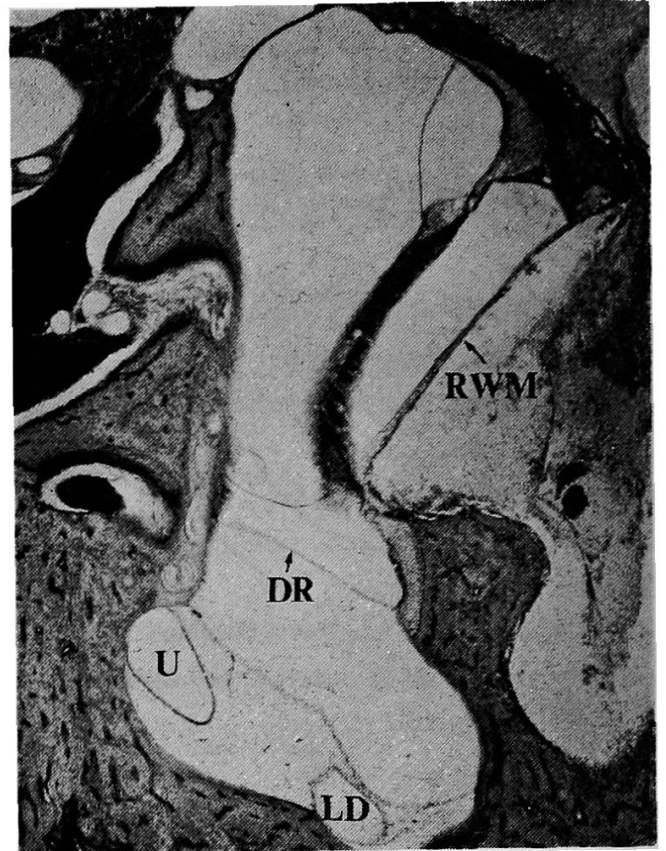

図 5 (No. 61) 図 4. と同耳. ductus reuriens (DR) が著しく拡張している.

RWM : 正円空膜, $U$ ：卵形囊, LD : 外側膜 半規管

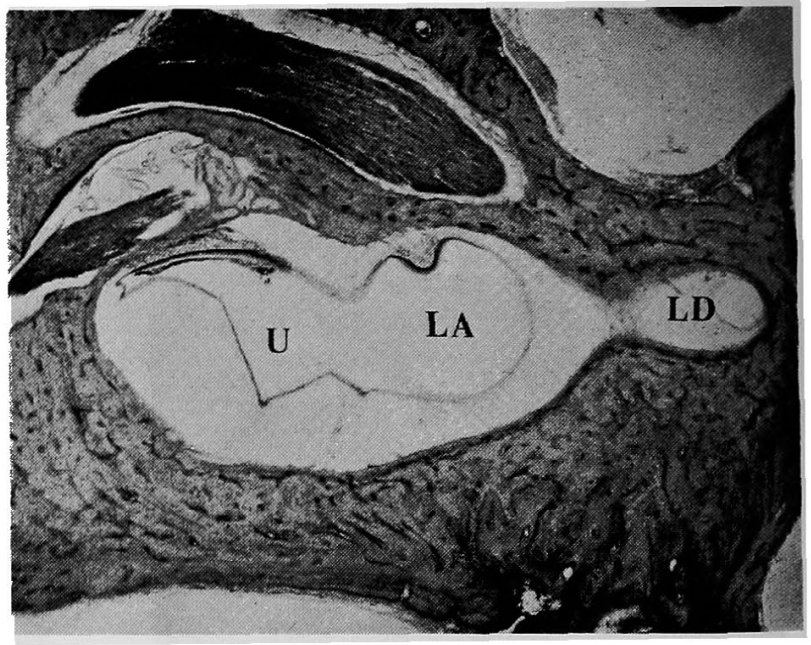

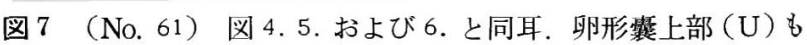
collapse している.

LA : 外側半規管膨大部, LD : 外側半規管 
小西論文附図 (3)

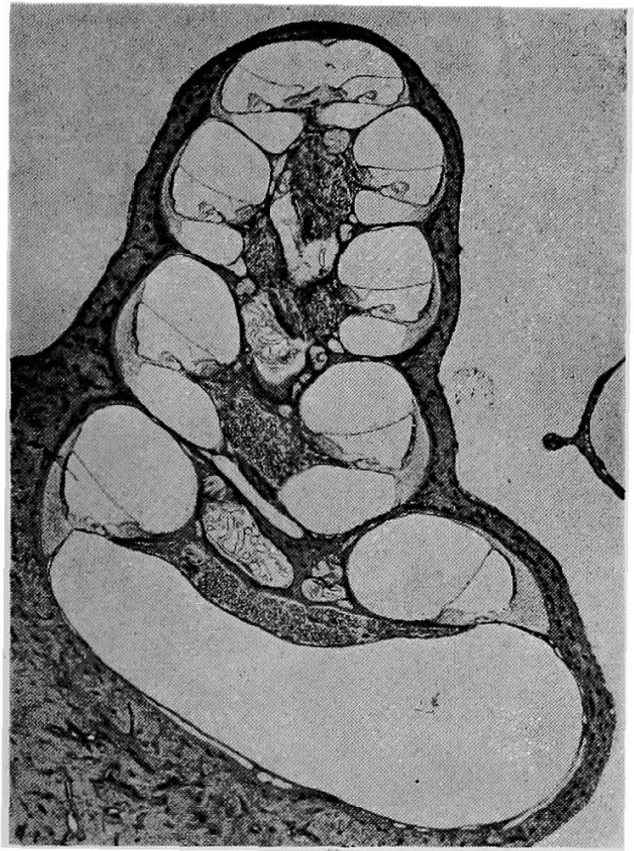

図 8 （No. 38） 内リンパ管閉塞後15日目に膜半規 管を切断し, その 1 週後の蝸牛軸切片標本の 顕微鏡写真. 蝸牛管の拡張は頂回転でやや残 存しているが，その他では全回転にわたつて 消失している.

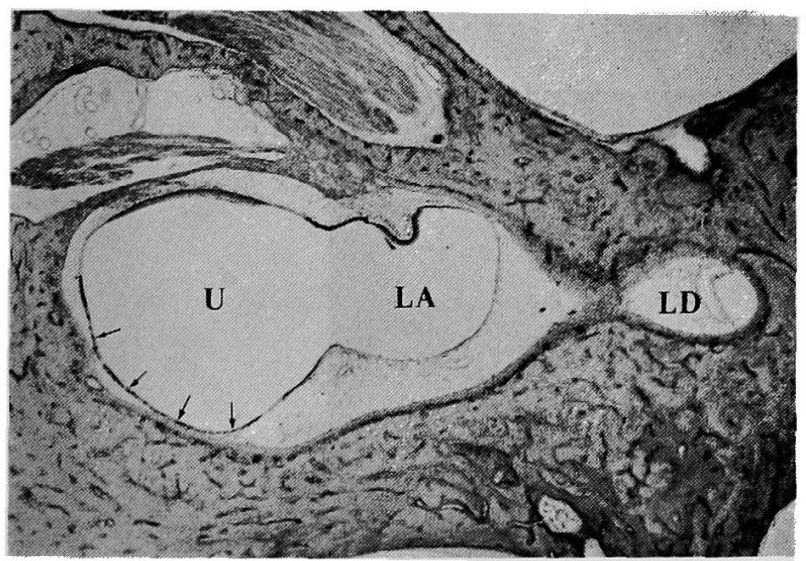

図10（No. 38）図 8. および9.と同耳、卵形囊上部（U）は抬 張し，外側膜半規管 (LD) は collapse している。 LA：外側半規管膨大部

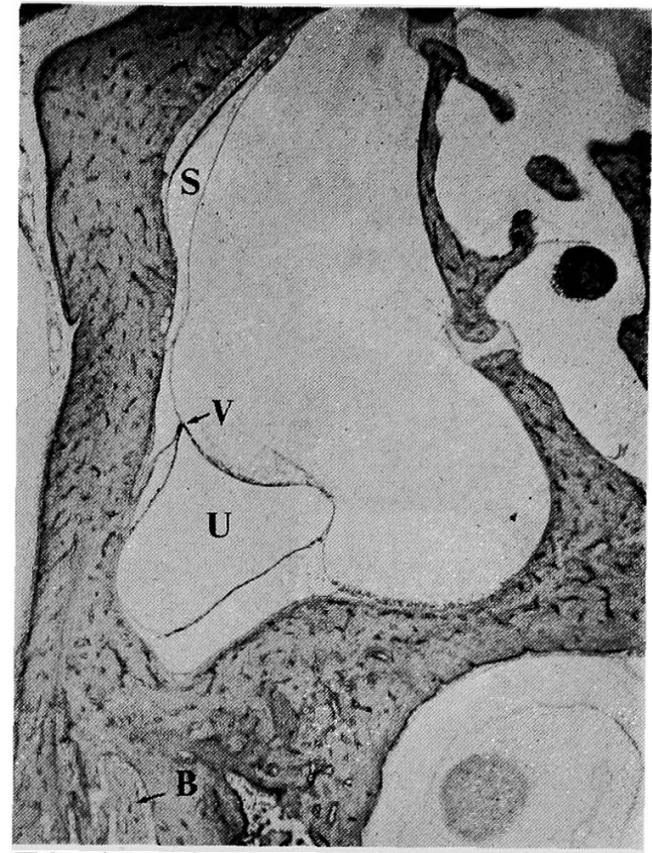

図 9 (No. 38) 図 8. と同耳の前庭顕微鏡写真 球形慗（S）と卵形露下部（U）は collapse し, valve (V) も閉鎖している。破壊され た内リンハ襄の部分は新生骨組織 (B) で充 塡されている.

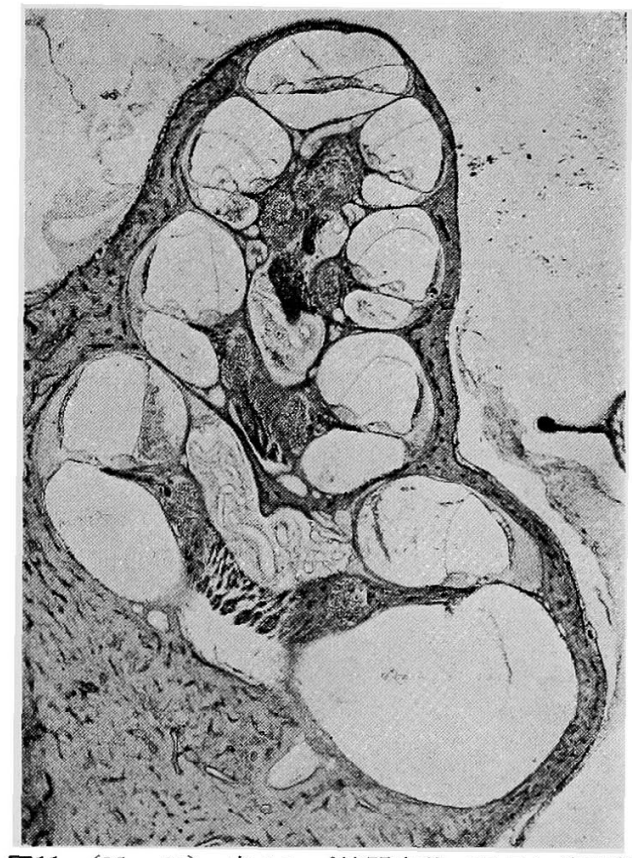

図11（No. 58） 内リンパ管閉塞後15日目に膜半規 管を切断し, その 1 日後の蝸牛軸切片標本の 顕微鏡写真. 蝸牛管の顕著な抾張が全回転に 見られ, 赤血球, 円形細胞, 多核球が外リン パ腔に存在寸る.同耳 $の$ ductus reuniens, 球 形巽, 卵形霆も著しく抬張し, 前庭外リンパ 腔内にも赤血球，白血球が存在している. 


\section{小西論文附図 (4)}

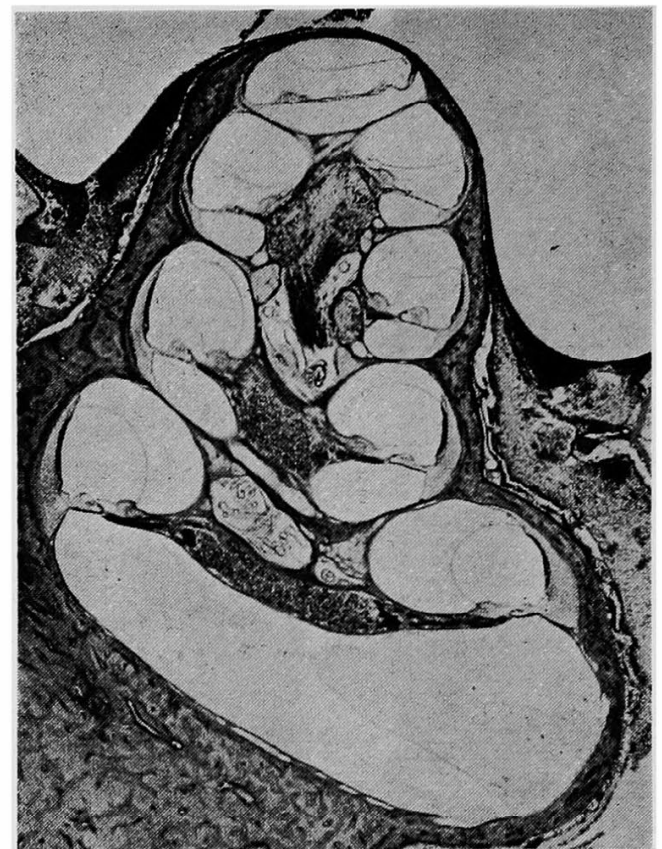

図12（No. 54）内リンパ管閉塞後15日目に膜半規 管を切断し, その 1 週後の蝸牛軸切片標本の 顕微鏡写真. 蝸牛管は全回転にわたり著しく 拡張し，基底回転の鼓室階に白血球が浸潤し ている. 同耳の ductus reuniens, 球形囊, 卵 形囊も拡張している。取腔に化膿性炎症が 見られる.

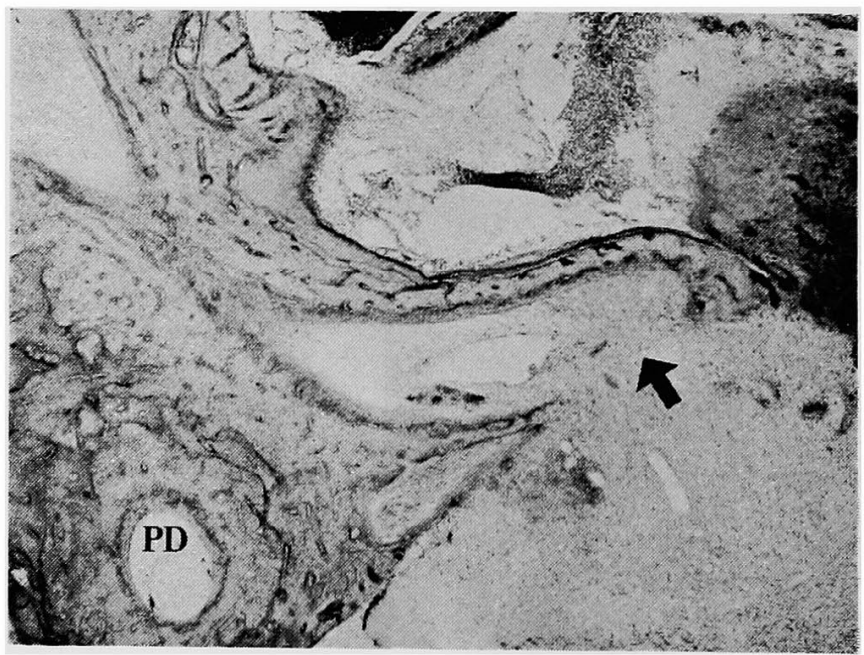

図13（No. 54）図 12. と同耳の外側半規管の顕微鏡写真. 外側 骨半規管の開空部より線維性結合織が増殖侵入し管内を充 畦している (知印). PD：後半規管 